\title{
The Impact of FDI and Financial Sector Development on Economic Growth: Empirical Evidence from Asia and Oceania
}

\author{
Yen Li Chee \\ Economic and Business Modelling Unit, School of Business \\ Monash University Sunway Campus \\ Jalan Lagoon Selatan, Bandar Sunway, 46150, Selangor, Malaysia \\ Tel: 60-3-5514-6000 E-mail: chee.yen.li@buseco.monash.edu.my \\ Mahendhiran Nair (Corresponding author) \\ Economic and Business Modelling Unit, School of Business \\ Monash University Sunway Campus \\ Jalan Lagoon Selatan, Bandar Sunway, 46150, Selangor, Malaysia \\ Tel: 60-3-5514-6287 E-mail: mahendhiran.nair@buseco.monash.edu.my
}

\begin{abstract}
This paper empirically examines if financial sector development is an important precondition for foreign direct investment (FDI) to enhance economic growth in the Asia-Oceania region. The study will also examine whether the impact is dependent on the stages of development of the countries. Panel data methods (fixed effects-estimator and random effects-estimator) were used to analyse the relationship between FDI, financial sector development and economic growth on a sample of 44 Asia and Oceania countries for the period 1996-2005. The empirical analysis showed that financial sector development enhances the contribution of FDI on economic growth in the region. It also showed that the complementary role of FDI and financial sector development on economic growth is most important for least developed economies in the region. Key strategies to enhance the role of FDI and financial development on economic growth in developing and least developed Asia and Oceania countries are also discussed in the paper.
\end{abstract}

Keywords: FDI, Financial development, Economic growth, Panel data methods, Asia, Oceania

\section{Introduction}

The number of empirical studies examining the impact of foreign direct investment (FDI) and financial sector development on economic growth has been growing ever since the emergence of endogenous growth theory. In the FDI-growth literature, empirical studies have so far yielded mixed results on whether FDI contributes positively to economic growth (e.g. Balasubramanyam et al., 1996; Borensztein et al., 1998; Carkovic and Levine, 2005; Hansen and Rand, 2006). Meanwhile, in the financial development-growth literature, the empirical results were more conclusive; most studies found that financial sector development contributes positively to economic growth (e.g. Beck et al., 2000; Christopoulos and Tsionas, 2004; King and Levine, 1993a; Levine, et al., 2000).

However, more recent studies have shown that the positive growth impact of FDI is dependent on the extent of financial sector development in host countries. Hermes and Lensink (2003), Alfaro et al. (2004) among others, have provided empirical evidence supporting this proposition. Despite this, the number of empirical studies examining this complementary impact has been relatively small. Most of the cross-sectional empirical studies were not region specific (see Alfaro et al., 2004; Hermes and Lensink, 2003), except for the study by Omran and Bolbol (2003) which focuses on Arab countries. There are no studies that have examined the role of financial sector development in enhancing the contributions of FDI on economic growth in Asia and Oceania countries - a region that have seen some of most rapid economic growth over the last two decades. This study hopes to fill this gap in the literature.

Specifically, this paper is designed to address the following issues. First, it aims to assess whether FDI and financial sector development have separate and/or complementary impact on economic growth in the Asia-Oceania region. Second, this paper also seeks to distinguish the complementary effect of FDI and financial sector development in least developed, developing and developed Asia and Oceania countries. 
In this study, panel data methods (fixed effects-estimator and random effects-estimator) were used to gauge the dynamics between FDI, financial sector development and economic growth in the Asia-Oceania region. Hence forth, the fixed effects-estimator and random effects-estimator are denoted as FE-estimator and RE-estimator, respectively. The empirical analysis is performed on a sample of 44 countries for a 10 year period (1996 to 2005).

The rest of this paper is structured as follows. Section II presents an overview of the literature on FDI, financial sector development and economic growth. This is followed by Section III, which outlines the model and the econometric methodology (traditional panel data methods) employed in this study. Section IV reports the empirical findings. Policy implications are discussed in Section V. Finally, Section VI concludes by suggesting some avenues for future research.

\section{Literature Review}

The role of FDI and financial sector development on economic growth has been widely discussed in the literature. De Mello (1997) argued that FDI enhances long run economic growth via technological progress, capital accumulation and human capital augmentation. The role of financial sector development on economic growth was first studied by Schumpeter (1911). Later study by Patrick (1966) argued that financial sector induces economic growth via the following channels: reallocation of resources from traditional to growth-inducing sectors and the promotion of entrepreneurship in growth-inducing sectors. More recent studies have used the endogenous growth theory approach to study the role of financial sector development of economic growth. Greenwood and Jovanovic (1990) showed that financial institutions play an important role in collecting and analysing information of firms and markets. King and Levine (1993b) also argued that financial development increases the return on innovation by providing three services. These services include the following: effective evaluation of investment projects through the acquisition of information; ability to pool and mobilise household savings for innovative endeavours; and, ability to share and diversify risks to enhance innovation of intermediate goods.

The most recent studies have used the endogenous growth framework to capture the complementary impact of FDI and financial sector development on economic growth. In Hermes and Lensink (2003), the cost of innovation was specified as function of FDI, where the cost falls as FDI inflow increases (innovation is cheaper due to technology transfer from foreign to local firms). The study showed that financial sector development increases the speed of innovation and technological spillovers from FDI. Using the ordinary least square method, the study showed that FDI will only have a positive impact on economic growth if the domestic financial sector is well-developed. Similar result was obtained by Alfaro et al. (2004) using banking sector indicators and stock market indicators.

Using panel data analysis, Omran and Bolbol (2003) conducted pooled OLS on 17 Arab countries and found that the impact of FDI on economic growth depends on development of the financial sector. Meanwhile, using the difference GMM estimator, Bailliu (2000) found that capital flows can only enhance economic growth in countries with sufficiently-developed financial sector.

Choong et al. (2004) analysed the complementary impact using Johansen multivariate cointegration technique and Granger Causality test for three developed countries (Japan, US, UK) and six East Asian countries. The study concluded that in the long run, financial sector development is crucial for FDI to have positive effects on economic growth in seven out of nine countries examined, while short run causality tests revealed that financial sector development is important in six out of nine countries examined. In a later study, Choong, et al. (2005) applied the bounds test and unrestricted error correction model (UECM) approach on Malaysia and found similar conclusion for both the long run and the short run. This study found the short run elasticities for FDI, financial sector development and the complementary impact to be higher than their corresponding long run elasticities.

On the other hand, Alfaro et al. (2006) proposed a theoretical model where financial sector development influences the extent to which FDI promotes higher economic growth in host countries via backward linkages. Specifically, by easing credit constraints via lower lending and borrowing rates, financial sector development is able to facilitate linkages between foreign firms and domestic firms. The calibration analysis showed that countries with highly developed financial sector tend to have higher returns of FDI on economic growth.

There are also a number of studies that have shown that the complementary hypothesis is not supported. For example, Durham (2004) empirically showed that the complementary effect between FDI and financial sector development was not statistically significant in impacting economic growth. This study employed stock market indicator and accounted for simultaneity bias. On the contrary, Carkovic and Levine (2005) applied system 
GMM estimator and found that financial sector development was not important in influencing FDI to contribute to economic growth.

In summary, the studies reviewed have insofar been inconclusive on whether the complementary effect of FDI and financial sector development is important in facilitating economic growth. Hence, this study will re-assess this relationship for the case of Asia and Oceania countries using traditional panel data methods.

\section{Data and Econometric Methodology}

The econometric model for this empirical analysis is specified as:

$$
\begin{aligned}
\text { growth }_{i t}= & \beta_{0}+\beta_{1} F D I_{i t}+\beta_{2} F_{i n D e v}+\beta_{3}\left(F D I_{i t} \times F i n D e v_{i t}\right)+\beta_{4}\left(d L D C_{i} \times F D I_{i t} \times F i n D e v_{i t}\right) \\
& +\beta_{5}\left(d D C_{i} \times F D I_{i t} \times F i n D e v_{i t}\right)+\mathbf{P}_{i t}^{\prime} \boldsymbol{\theta}+\varepsilon_{i t}
\end{aligned}
$$

where $\quad$ Growth $=$ per capita GDP growth rate

$F D I=$ FDI to GDP ratio

FinDev $=$ financial sector development proxy to GDP ratio

$d L D C=$ dummy variable for least developed countries

$d D C=$ dummy variable for developing countries

$\mathbf{P}^{\prime}$ consists of other variables that affect economic growth (control variables)

subscript $i$ denotes country $i$

subscript $t$ denotes year $t$

Model (1) is an extension of the econometric model employed in previous empirical studies by including the variables $d L D C \times F D I \times F i n D e v$ and $d D C \times F D I \times F i n D e v$. Note that (1) is expressed in panel data form.

The term FDI $\times$ FinDev is used to capture the role of financial sector development in enhancing the contributions of FDI on economic growth. FDI $\times$ FinDev is also interacted with country classification dummies $(d L D C$ and $d D C)$ to capture the difference in the complementary effect of FDI and financial sector development for developed, developing and least developed Asia and Oceania countries. The dummies are not included 'on their own' in model (1) because of econometric specification problems, which is further explained in the next sub-section.

Taking partial derivative of (1) with respect to $F D I$, one obtains:

$$
\frac{\text { growth }_{i t}}{\partial F D I_{i t}}=\beta_{1}+\beta_{3} \text { FinDev }_{i t}+\beta_{4}\left(d L D C_{i} \times \text { FinDev }_{i t}\right)+\beta_{5}\left(d D C_{i} \times \text { FinDev }_{i t}\right)
$$

where $\beta_{1}$ represents the marginal effect of FDI on economic growth, ceteris paribus. Meanwhile, $\beta_{3}, \beta_{4}$ and $\beta_{5}$ represent the growth impact of FDI that is dependent on the level of financial sector development, ceteris paribus. For developed countries $(d L D C=0$ and $d D C=0)$, the role of financial sector development in enhancing the contribution of FDI on economic growth is captured by $\beta_{3}$. Meanwhile, the additional contribution for developing countries $(d L D C=0$ and $d D C=1)$ is $\beta_{3}+\beta_{5}$. Lastly, the role of financial sector development in deepening the contribution of FDI on economic growth in least developed countries $(d L D C=1$ and $d D C=0)$ is $\beta_{3}+\beta_{4}$.

The parameter $\beta_{3}$ is expected to be positive because FDI is more growth enhancing in countries with better-developed financial sector (Hermes and Lensink, 2003). Note that $\beta_{4}$ and $\beta_{5}$ are also expected to be positive, based on Solow's (1956) convergence argument. Developed countries have achieved a steady state, where economic growth rates are low and stable. On the contrary, least developed and developing countries have the potential to achieve higher status of development through economic growth. Therefore, any changes in factors contributing to economic growth will have a higher impact in least developed and developing economies compared to developed countries. From this perspective, one can expect that least developed countries with the same level of financial sector development will experience greater growth impact from FDI compared developing countries of similar level of financial sector development. Similarly, developing countries will experience greater growth impact from FDI compared to developed countries with the same level of financial sector development. 


\subsection{The Empirical Methodology}

This study employed the following traditional panel data methods: the FE-estimator and the RE-estimator. The FE-estimator allows the unobserved effects (country specific effects) to be correlated with the regressors, while the RE-estimator does not allow for such correlation. Both the FE- and RE-estimators are consistent when the unobserved effects are uncorrelated with the observed regressors. However, only the FE-estimator is consistent when the unobserved effects are correlated with the observed regressors. Hence, the appropriateness of the estimator (FE-estimator or RE-estimator) is determined by testing whether the unobserved effects are correlated with the regressor. This is known as the Hausman (1978) test.

An important assumption for both the $\mathrm{FE}$ and $\mathrm{RE}$ estimators is that the idiosyncratic errors must be homoskedastic and uncorrelated across time. If the assumptions of the errors are violated, the FE estimator will still be a consistent estimator, but will be an inefficient and biased estimator (Baltagi, 2005). It is very likely that our model exhibits heteroskedasticity (HSK) or serial correlation. To correct for serial correlation and heteroskedasticity, model (1) will be estimated using FE Generalised Least Squares [FEGLS] for the FE model. For the RE model, (1) will be estimated using the White's robust standard errors.

It is important to note that any regressors that do not vary across time for each cross section unit cannot be included into the FE model as a time-constant regressor leads to perfect multicollinearity. In this case, the FE estimator is undefined. Although time-invariant variables cannot be included individually into the model, they can be interacted with other regressors. However, the time-invariant variables can be included into the RE model. To obtain comparable results using both methods, we do not include the dummies for developing and least developed countries 'on their own' in model (1).

\subsection{The Data}

The empirical analysis was performed using data from 44 Asia and Oceania countries over a span of 10 years (1996 - 2005). Data was collected for countries classified under the Asia region and the Oceania region according to the United Nations (UN) Statistics Division Geographical Region Classification. A list of countries included in this analysis is provided in Table A.1 of the Appendix.

Note that previous panel data studies have used five-year averages to remove short run fluctuations in business cycles (Temple, 1999). However, it was impossible to employ such intervals as this study was constrained by data availability. Thus, annual data was used in this study.

The dependent variable in this study is economic growth. Real GDP per capita growth rate (deflated using GDP deflator of base year 2000) was used to measure for economic growth. As for the explanatory variables, real FDI inflow as a percentage of GDP was used to measure FDI. This study employed the following proxies to measure financial sector development:

- Liquid Liabilities - Ratio of financial system liquid liabilities (usually M3, or M2 when M3 is unavailable) to GDP

- Private Credit - Value of credits to private sector allocated by financial intermediaries divided by GDP

Due to its advantages over other proxies, Levine, Loayza and Beck (2000) argued that Private Credit was a better measure for financial sector development compared to Liquid Liabilities. Both financial development indicators were deflated using CPI of base year 2000 or, if unavailable, GDP deflator of the same base year.

The interaction between the FDI and financial development indicators was used to capture the complementary impact of FDI and financial sector development on economic growth. Using the 2005 World Bank Analytical Classification criterion, Asia and Oceania countries were classified into:

- Least developed countries - low income

- Developing countries - lower middle income and upper middle income

- Developed countries - high income

The developed countries category was designated as the reference category. Only two dummy variables are required to represent these three categories to avoid dummy variable trap. These two dummies were interacted with the interaction term of FDI and financial development indicator to capture differences in the complementary growth effect of FDI and financial sector development in least developed, developing and developed. Temple (1999) suggested that these interaction dummies are useful in detecting heterogeneity.

Other explanatory variables (control variables) include initial GDP per capita, gross capital formation (GCF) as $\%$ of GDP, government consumption expenditure as \% of GDP, trade openness, secondary enrolment ratio 
(proxy for level of human capital), population growth and government effectiveness index. Definition of all the variables employed in this analysis, along with the data sources is provided in Table A.2 and Table A.3 of the Appendix.

There are concerns about multiplying two continuous variables in regression analysis, as it produces another continuous variable which may not be meaningful when the bases of these variables are different. Hence, this study proposed to construct indices for FDI, Liquid Liabilities, Private Credit and secondary enrolment ratio. Note that FDI Liquid Liabilities and Private Credit have the same base, but FDI and secondary enrolment have different bases. Thus, the construction of indices for variables with different bases makes the interpretation more meaningful as it standardises the base to 100 .

Finally, availability of quality data is a known problem when analysing developing and least developed countries (Temple, 1999). Therefore, it is not surprising that missing data is inevitable for countries included in this analysis. Missing observations for secondary enrolment ratio were estimated using non-linear time-trend interpolation method for the period 1996 to 1998. Government effectiveness index was also interpolated because the data was only available for every two years between 1996 and 2002. The missing figures were computed as simple averages of the figures from period $(t-1)$ and $(t+1)$.

\section{Empirical Results}

In this paper, the model in (1) was estimated using the FE-estimator and RE-estimator. Based on the Hausman (1978) test statistics, the null hypothesis of the RE estimates being asymptotically efficient and consistent was rejected at any conventional level of significance. This was true for both financial development indicators, namely Liquid Liabilities and Private Credit. Hence, the FE-estimator was found to be more appropriate for estimating the model in (1). The $1^{\text {st }}$ order serial correlation tests do not indicate the presence of correlation in the FE residuals. To account for potential cross-sectional contemporaneous correlation in the residuals, model (1) was estimated using FEGLS. The results are reported in Table 1. For comparison purpose, the results obtained from RE-estimator with White's robust standard errors are also reported. In contrast to the RE models, the estimated FEGLS models are more appropriate for obtaining robust statistical inferences as they do not exhibit the problem of $1^{\text {st }}$ order serial correlation in the residuals. Furthermore, the Jacque-Bera test statistics showed that the null hypothesis of normality in the FEGLS residuals cannot be rejected at any conventional level.

Based on the FEGLS regressions, the individual impact of FDI on economic growth was found to be positive and significant, regardless of the financial development indicators employed. In contrast, the RE regressions suggest that the impact of FDI on economic growth was statistically insignificant. As FEGLS is a more appropriate estimator, the results imply that FDI contributes positively to economic growth, ceteris paribus. This result is consistent with some studies in the FDI-growth literature (e.g. Balasubramanyam, et al., 1996; De Mello, 1999; Ram and Zhang, 2002). However, the result is inconsistent with the results found in the literature examining the complementary growth impact of FDI and financial sector development such as Hermes and Lensink (2003), Omran and Bolbol (2003) and Alfaro et al. (2004). These studies found that the individual impact of FDI on economic growth were both negative and statistically significant or positive but statistically insignificant.

Meanwhile, the individual impact of financial sector development on economic growth was found to be negative, irrespective of the indicators used. However, it was only statistically significant in the FEGLS regression where Private Credit was used as the proxy for financial sector development. Note that the negative impact was found to be statistically significant in all the RE regressions. Hence, the results obtained here suggest that its significance depends on the proxy used in measuring financial sector development. One possible explanation for the negative impact of financial sector development on economic growth is financial fragility, which was discussed in Loayza and Ranciere (2006).

For the FEGLS regressions, the interaction term FDI $\times$ FinDev was found to be positive and significant, regardless of the financial development indicators employed. The Wald test result for $H_{0}: \beta_{3}=\beta_{4}=\beta_{5}=0$ suggests that FDI and financial sector development are complementary in facilitating economic growth, ceteris paribus. The null hypothesis was rejected for both models. Similar results were observed in the RE regressions. This conclusion is also consistent with previous empirical studies such as Hermes and Lensink (2003), Omran and Bolbol (2003), Alfaro et al. (2004), and Choong, Yusop and Soo (2004).

In addition, the null hypothesis of $\beta_{4}=\beta_{5}=0$ was rejected for the FEGLS regressions. The same result was obtained from the RE regressions. This implies that the complementary impact of FDI and financial sector development on economic growth was different in least developed, developing and developed countries, ceteris paribus. 
Since the Wald tests conclude that the complementary impact was different in the three groups of countries, we are interested to determine which of the two groups differs. Recall that the reference group is developed countries. The interaction term $d L D C \times F D I \times$ FinDev was positive and significant in both the FEGLS and RE regressions, irrespective of the financial development indicators employed. These results suggest that the complementary impact of FDI and financial sector development is significantly greater in least developed compared to developed countries. Hence, for the same amount of improvement in the financial sector, FDI will have greater impact on economic growth in least developed countries compared to developed countries.

In contrast, the interaction term $d D C \times F D I \times$ FinDev was insignificant in all the FEGLS and RE regressions. The estimated coefficient was positive when Liquid Liabilities was used, but negative when Private Credit was used in the FEGLS regression. As for the RE regressions, the estimated coefficient for this interaction term were positive, for both Liquid Liabilities and Private Credit. Although the complementary impact in developing countries was generally greater than developed countries and lower than least developed countries, this difference were statistically insignificant in both models.

To sum up, the empirical results suggest that financial sector development is important for FDI to contribute to economic growth in the Asia-Oceania region. This complementary impact of FDI and financial sector development on economic growth in developing countries was as important as it was in developed countries. But the complementary impact was more important in least developed countries because the impact on economic growth was higher. This somehow provides evidence to support Solow's (1956) convergence argument in least developed countries.

For the control variables, only the results obtained from FEGLS are discussed here. As indicated in Table 1, control variables that were statistically significant irrespective of whether Liquid Liabilities or Private Credit was used in the model include GCF, government consumption, initial GDP per capita, population growth, government effectiveness index, interaction between the least developed countries dummy and trade openness, as well as the interaction between FDI and secondary enrolment ratio. All the control variables have the expected signs, except government consumption and the interaction between FDI and secondary enrolment ratio.

Barro and Sala-i-Martin (1995) attributed the negative impact of government on economic growth to unproductive public sector or some aspects of bad government such as corruption, which is likely to be captured by the variable. These factors have the tendency to hinder economic growth. The fact that the interaction effect of FDI and secondary enrolment ratio on economic growth was negative and statistically significant, irrespective of whether Liquid Liabilities or Private Credit was used as the proxy for financial sector development was quite puzzling. Despite being inconsistent with previous studies (Borensztein et al., 1998; Hermes and Lensink 2003; $\mathrm{Li}$ and Liu, 2005) where this interaction term was positive, an interpretation for this negative coefficient is that the contribution of FDI to growth decreases as secondary enrolment ratio increases. It can be argued that countries with a higher level of human capital are more likely to engage in R\&D locally, which is growth enhancing according to Romer (1990). Hence, an increase in the level of human capital reduces a country's dependency on FDI (foreign technology) for economic growth. Good examples of countries in Asia that have used domestic talent to enhance economic development are Singapore, Korea, Taiwan and Hong Kong.

The positive impact of GCF on growth implies that higher domestic capital investment contributes to economic growth in the region. Meanwhile, the negative impact of population growth suggests that increased population growth in the region will hinder economic growth. The positive impact of government effectiveness implies that improved government effectiveness will enhance economic growth in the region. Finally, the results in Table 1 suggests that trade openness is detrimental to economic growth in the region's least developed economies. The interaction between FDI and government effectiveness was found to be positive for both the FEGLS models, but were found to be statistically insignificant at the conventional level. Furthermore, similar results were obtained with the inclusion of this interaction variable. Thus, the interaction between FDI and government effectiveness was not included in the final models reported in Table 1 to maintain a more parsimonious model.

\section{Discussion}

The empirical analysis suggests that financial sector development is important for FDI to facilitate economic growth in Asia and Oceania countries, regardless of these countries' stages of economic development. From the policy perspective, the empirical results obtained in this study have very important implications for Asia and Oceania countries, especially for developing and under-developed economies. Hence, this section is devoted to address some policy issues with respect to the complementary impact of FDI and financial sector development on economic growth. 
Countries in this region should re-consider the sequence of financial sector development policies and FDI policies, similar to the recommendation made by Hermes and Lensink (2003), Alfaro et al. (2004) and others. These countries should improve their domestic financial system prior to liberalising the capital account and embarking into policies that encourage greater FDI inflows. For example, these countries should formulate policies to encourage the development of effective and efficient financial institutions and markets that meet the needs of a knowledge-based economy. Examples of policies to strengthen the financial sector include developing human capital in this sector, maintaining good governance, and fostering collaboration between developed, developing and least developed countries.

In terms of FDI promotion policies, countries in the Asia-Oceania region should formulate a range of policies aimed at attracting FDI into key sectors of the economy. These include investment incentives, development of basic infrastructure, policies to promote technology transfers from foreign firms, and initiatives to encourage FDI in the R\&D sector. The last two strategies are particularly important for building innovative capacities in these countries, which will subsequently lead to technological progress.

Human capital development policies are also important for the development of a knowledge-intensive economy. Both the governments and enterprises have an important role to play in raising the level of skilled workforce in the region. Governments should provide fiscal and non-fiscal incentives for human capital development, while enterprises should encourage their employees to engage in further education and training. The private sector participation can be increased if the appropriate taxation system was in place to reduce the burden of training and developing the labour force.

It is also important that effort must not only be given in increasing the supply of skilled workers in developing and least developed Asia and Oceania countries, but also in preventing brain-drain from these countries to more developed countries (Vaithilingam et al., 2006). The build-up of skilled workforce and research personnel in the region will lead to greater innovative capacity of the region, hence, raising the productivity level in the region. It will also lead to the substitution of foreign technology to local technology. This reduces a country's dependency on foreign technology to stimulate economic growth.

In summary, the positive impact of FDI on economic growth can only be achieved if developing and least developed countries in the Asia-Oceania region invest in financial sector development, education and training and adoption of new technology.

\section{Conclusion}

In this paper, the role of FDI and financial sector development on economic growth in Asia and Oceania countries were examined. Panel data analysis was performed to assess if FDI and financial sector development have separate and/or complementary impact on economic growth in these countries. The study also empirically examined whether this complementary impact differs amongst least developed, developing and developed countries. The empirical analysis was performed on a sample of 44 Asia and Oceania countries for the period 1996-2005.

The main findings of this study are as follows:

- FDI, on its own, contribute to economic growth;

- financial sector development plays an important role in further enhancing the contributions of FDI on economic growth; thus, their impact on economic growth is complementary; and

- the complementary growth impact of FDI and financial sector development is most important for least developed countries, while being equally important for developing and developed economies in the region.

The empirical findings have important implications in stimulating economic growth in Asia and Oceania countries. A range of initiatives for enhancing the financial sector, attracting FDI and developing human capital are discussed in this study. But, the recommendations made in this study were very general for the region, and not country-specific. If these recommendations were to be implemented, countries in the region should evaluate the costs and benefits of these policies prior to implementation.

Future studies should focus on identifying if financial sector development is an important pre-condition for FDI to contribute positively to economic growth in various other regions such as Africa, Latin America and Eastern Europe. Region-specific evidences will enhance policy recommendations for these regions, and at the same time, reduces the application of general policy recommendations which may not be relevant to these regions. 


\section{References}

Alfaro, L., Chanda, A, Kalemli-Ozcan, S. \& Sayek, S. (2004). FDI and Economic Growth: The Role of Local Financial Markets. Journal of International Economics, 64, 89-112.

Alfaro, L., Chanda, A., Kalemli-Ozcan, S. \& Sayek, S. (2006). How Does Foreign Direct Investment Promote Economic Growth? Exploring the Effects of Financial Markets on Linkages. NBER Working Paper no. 12522, National Bureau of Economic Research, Cambridge, MA.

Arestis, P. \& Demetriades, P. (1997). Financial Development and Economic Growth: Assessing the Evidence The Economic Journal, 107, 783-799.

Bailliu, J.N. (2000). Private Capital Flows, Financial Development and Economic Growth in Developing Countries. Bank of Canada Working Paper no. 2000-15, Bank of Canada, Ontario.

Balasubramanyam, V.N., Salisu, M. \& Sapsford, D. (1996). Foreign Direct Investment and Growth in Ep and Is Countries. The Economic Journal, 106, 92-105.

Baltagi, B.H. (2005). Econometric Analysis of Panel Data. (3rd ed.). England: John Wiley \& Sons Ltd.

Baltagi, B.H. \& Chang, Y-J. (1994). Incomplete Panels: A Comparative Study of Alternative Estimators for the Unbalanced One-Way Error Component Regression Model. Journal of Econometrics, 62, 67-89.

Barro, R.J. \& Sala-i-Martin, X. (1995). Economic Growth. New York: McGraw-Hill.

Beck, T., Levine, R. \& Loayza, N. (2000). Finance and the Sources of Growth. Journal of Financial Economics, $58,261-300$.

Borensztein, E., Gregorio, J.D. \& Lee, J-W. (1998). How Does Foreign Direct Investment Affect Economic Growth. Journal of International Economics, 45, 115-135.

Carkovic, M. \& Levine, R. (2005). Does FDI Accelerate Economic Growth? In T.H. Moran, E.M.Graham, \& M. Blomström, Does Foreign Direct Investment Promote Growth?. Washington DC: Institute for International Economics. pp. 195-220.

Choong, C-K., Yusop, Z. \& Soo, S-C. (2004). Foreign Direct Investment, Economic Growth and Financial Sector Development: A Comparative Analysis. ASEAN Economic Bulletin, 21, 278-289.

Choong, C-K., Yusop, Z. \& Soo, S-C. (2005). Foreign Direct Investment and Economic Growth in Malaysia: The Role of Domestic Financial Sector. The Singapore Economic Review, 50, 245-268.

Chowdhury, G. (1991). A Comparison of Covariance Estimators for Complete and Incomplete Panel Data Models. Oxford Bulletin of Economics and Statistics, 31, 83-93.

Christopoulos, D.K. \& Tsionas, E.G. (2004). Financial Development and Economic Growth: Evidence from Panel Unit Root and Cointegration Tests. Journal of Development Economics, 73, 55-74.

De Mello, L.R. (1999). Foreign Direct Investment-Led Growth: Evidence from Time Series and Panel Data. Oxford Economic Papers, 51, 133-151.

Durham, J.B. (2004). Absorptive Capacity and the Effects of Foreign Direct Investment and Equity Foreign Portfolio Investment on Economic Growth. European Economic Review, 48, 285-306.

Hansen, H. \& Rand, J. (2006). On the Causal Links between FDI and Growth in Developing Countries. The World Economy, 29, 21-41.

Hausman, J.A. (1978). Specification Tests in Econometrics. Econometrica, 46, 1251-1271.

Hermes, N. \& Lensink, R. (2003). Foreign Direct Investment, Financial Development and Economic Growth. The Journal of Development Studies, 40, 142-163.

King, R.G. \& Levine, R. (1993). Finance and Growth: Schumpeter Might Be Right. The Quarterly Journal of Economics, 108, 717-737.

Levine, R., Loayza, N. \& Beck, T. (2000). Financial Intermediation and Growth: Causality and Causes. Journal of Monetary Economics, 46, 31-77.

Li, X. \& Liu, X. (2005). Foreign Direct Investment and Economic Growth: An Increasingly Endogenous Relationship. World Development, 33, 393-407.

Loayza, N.V. \& Ranciere, R. (2006). Financial Development, Financial Fragility and Growth. Journal of Money, Credit and Banking, 38,1051-1076. 
Mátyás, L. \& Lovrics, L. (1991). Missing Observations and Panel Data: A Monte-Carlo Analysis. Economics Letters, 37, 39-44.

Nair-Reichert, U. \& Weinhold, D. (2001). Causality Tests for Cross-Country Panels: A New Look at FDI and Economic Growth in Developing Countries. Oxford Bulletin of Economics and Statistics, 63, 153-171.

Omran, M. \& Bolbol, A. (2003). Foreign Direct Investment, Financial Development and Economic Growth: Evidence from the Arab Countries. Review of Middle East Economics and Finance, 1, 231-249.

QMS. (2007). EViews 6 User Guide. United States: Quantitative Micro Software.

Ram, R. \& Zhang, K.H.. (2002). Foreign Direct Investment and Economic Growth: Evidence from Cross-Country Data for the 1990s. Economic Development and Cultural Change, 51, 205-215.

Romer, P. M. (1990). Endogenous Technological Change. Journal of Political Economy, 98, S71-S102.

Solow, R. M. (1956). A Contribution to the Theory of Economic Growth. Quarterly Journal of Economics, 70, 65-94.

Temple, J. (1999). The New Growth Evidence. Journal of Economic Literature, 37, 112-156.

Vaithilingam, S., Nair, M. \& Samudram, M. (2006). Key Drivers for Soundness of the Banking Sector: Lessons for Developing Countries. Journal of Global Business and Technology, 2, 1-11.

Wooldridge, J.M. (2002). Econometric Analysis of Cross Section and Panel Data. London: The MIT Press. 
Table 1. Traditional Panel Data Results

Dependent variable - Real GDP per capita growth rate

\begin{tabular}{|c|c|c|c|c|}
\hline & \multicolumn{2}{|c|}{ Liquid Liabilities } & \multicolumn{2}{|c|}{ Private Credit } \\
\hline & $\begin{array}{c}\text { Fixed Effects } \\
\text { GLS } \\
\end{array}$ & Random Effects & $\begin{array}{c}\text { Fixed Effects } \\
\text { GLS } \\
\end{array}$ & Random Effects \\
\hline \multirow{2}{*}{ FDI Index } & $0.165869 * * *$ & 0.084788 & $0.238775^{*}$ & 0.085642 \\
\hline & {$[1.934014]$} & {$[0.925727]$} & {$[3.314835]$} & {$[1.201682]$} \\
\hline \multirow{2}{*}{ Financial Development Index } & -0.014159 & $-0.093037 *$ & $-0.073500^{* *}$ & $-0.119328^{*}$ \\
\hline & {$[-0.371426]$} & {$[-4.889939]$} & {$[-2.515032]$} & {$[-3.035133]$} \\
\hline \multirow{2}{*}{$\begin{array}{c}(\text { FDI Index }) \times \quad \text { Financial Development } \\
\text { Index })\end{array}$} & $0.001821^{*}$ & $0.001644 *$ & $0.001407 * *$ & $0.001219 * *$ \\
\hline & [2.983589] & {$[5.207081]$} & {$[2.029355]$} & {$[2.240460]$} \\
\hline \multirow{2}{*}{$\begin{aligned}(\mathrm{dLDC}) & \times(\text { FDI Index }) \times(\text { Financial } \\
& \text { Development Index })\end{aligned}$} & $0.014940^{*}$ & $0.010782 * * *$ & $0.016492 *$ & $0.016807^{*}$ \\
\hline & {$[2.738317]$} & {$[1.894376]$} & {$[2.896596]$} & [3.190139] \\
\hline \multirow{2}{*}{$\begin{array}{l}(\mathrm{dDC}) \times(\text { FDI Index }) \times(\text { Financial } \\
\\
\text { Development Index })\end{array}$} & 0.000575 & 0.000377 & -0.001160 & 0.002762 \\
\hline & {$[0.318996]$} & [0.156698] & {$[-0.639160]$} & [1.181377] \\
\hline \multirow{2}{*}{ GCF/GDP } & $4.174314^{*}$ & $3.075682 *$ & $4.511102 *$ & $3.768960^{*}$ \\
\hline & {$[4.712855]$} & [2.618529] & {$[5.096210]$} & {$[2.614403]$} \\
\hline \multirow{2}{*}{ Government Consumption/GDP } & $-2.698094 * *$ & -1.110254 & $-2.194274 * * *$ & -1.435384 \\
\hline & {$[-2.300234]$} & {$[-0.635651]$} & {$[-1.852278]$} & {$[-1.062010]$} \\
\hline \multirow{2}{*}{ Trade Openness } & 3.913436 & -0.716780 & 4.284149 & -0.793913 \\
\hline & [1.433067] & {$[-1.455109]$} & {$[1.546742]$} & {$[-1.512970]$} \\
\hline \multirow{2}{*}{$(\mathrm{dLDC}) \times($ Trade Openness $)$} & $-8.447420 *$ & $-2.129962 *$ & $-8.365855^{*}$ & $-2.160245^{*}$ \\
\hline & {$[-2.789122]$} & {$[-5.149722]$} & {$[-2.709809]$} & {$[-5.014140]$} \\
\hline \multirow{2}{*}{$(\mathrm{dDC}) \times($ Trade Openness $)$} & -1.188523 & $-1.066976^{*}$ & -1.445070 & $-1.122587^{*}$ \\
\hline & {$[-0.405569]$} & {$[-3.875070]$} & {$[-0.479820]$} & {$[-3.964104]$} \\
\hline \multirow{2}{*}{ Secondary Enrolment Index } & 0.032867 & -0.003961 & 0.034533 & -0.006507 \\
\hline & {$[1.057961]$} & {$[-0.180657]$} & {$[1.151892]$} & {$[-0.243510]$} \\
\hline \multirow{2}{*}{$\begin{array}{c}(\text { FDI Index }) \times \\
\quad \text { (Secondary Enrolment } \\
\text { Index })\end{array}$} & $-0.003964 *$ & -0.001977 & $-0.004737 *$ & $-0.002013 * * *$ \\
\hline & {$[-2.849834]$} & {$[-1.403879]$} & {$[-3.696116]$} & {$[-1.653112]$} \\
\hline \multirow{2}{*}{ Initial GDP per capita } & $-7.006893 *$ & $-1.577180 * *$ & $-5.890366^{*}$ & $-1.306164 * *$ \\
\hline & {$[-3.669137]$} & {$[-2.156702]$} & {$[-2.803343]$} & {$[-2.409895]$} \\
\hline \multirow{2}{*}{ Population Growth } & $-0.556901 * * *$ & $-0.626809 *$ & $-0.634947 * *$ & $-0.782798^{*}$ \\
\hline & {$[-1.917586]$} & {$[-3.128638]$} & {$[-2.165841]$} & {$[-4.493691]$} \\
\hline \multirow{2}{*}{ Government Effectiveness Index } & $2.184555^{*}$ & 0.731672 & $1.948916^{* *}$ & $1.210381 * *$ \\
\hline & {$[2.747144]$} & {$[1.235357]$} & {$[2.464041]$} & {$[1.994570]$} \\
\hline Wald Test for Hypothesis (3.12) & $4.1926^{*}$ & $11.0452 *$ & $4.1066^{*}$ & $6.7556^{*}$ \\
\hline$(p$-value $)$ & $(0.0062)$ & $(0.0000)$ & $(0.0070)$ & $(0.0002)$ \\
\hline Wald Test for Hypothesis (3.13) & $3.8702 * *$ & $3.4224 * *$ & $4.7704 *$ & 5.1247 \\
\hline$(p$-value $)$ & $(0.0218)$ & $(0.0336)$ & $(0.0090)$ & $(0.0064)$ \\
\hline$R^{2}$ & 0.722648 & 0.267601 & 0.666724 & 0.286558 \\
\hline \multicolumn{5}{|l|}{ Diagnostic Tests: } \\
\hline Serial Correlation Test & -0.203965 & 7.0118 & -0.436995 & 6.8860 \\
\hline$(p$-value $)$ & $(0.8385)$ & $(0.000)$ & $(0.6624)$ & $(0.0000)$ \\
\hline Jacque-Bera Test & 5.7207 & 293.2494 & 4.0955 & 112.2696 \\
\hline (p-value) & $(0.0572)$ & $(0.0000)$ & $(0.1290)$ & $(0.0000)$ \\
\hline Hausman Test & \multirow{2}{*}{\multicolumn{2}{|c|}{$\begin{array}{l}52.5967 \\
(0.0000)\end{array}$}} & \multirow{2}{*}{\multicolumn{2}{|c|}{$\begin{array}{l}48.8638 \\
(0.0000)\end{array}$}} \\
\hline (p-value) & & & & \\
\hline
\end{tabular}

Note: $t$-statistics reported in parentheses and $p$-values reported in brackets. $*$ and $* * *$ denotes significance at $1 \%, 5 \%$ and $10 \%$. The $R^{2}$ and $\bar{R}^{2}$ are based on weighted statistics in GLS. Time dummies and constant are included in all estimations. 


\section{Appendix}

Table A.1. List of Countries

\begin{tabular}{cccc}
\hline Sub-region & Developed & Developing & Least Developed \\
\hline Central Asia & - & Kazakhstan & Kyrgyz Republic \\
Eastern Asia & Hong Kong, Macao, Japan, & China & Mongolia \\
Southern Asia & Korea & Iran, Maldives, & Bangladesh, India, Pakistan \\
South-Eastern & - & Indonesia, Malaysia, & Cambodia, Laos, Myanmar, \\
Asia & Singapore & Philippines, Thailand & Vietnam \\
Western Asia & Bahrain, Cyprus, & Armenia, Azerbaijan, Jordan, & Oman, \\
& Qatar, Saudi Arabia, United & Syrian Republic, & Turkey, Georgia \\
Arab Emirates, Kuwait, Israel & Australia, New Zealand & Fiji, Vanuatu, Samoa, Tonga
\end{tabular}

Note: Sub-regional classification was obtained from United Nation Statistical Division Geographical

Classification. Countries are classified into least developed, developing and developed countries based on World Bank Analytical Classification (Atlas Method). 
Table A.2. Data Source

\begin{tabular}{|c|c|}
\hline Data & Source \\
\hline \multirow{2}{*}{ FDI Inflows (US\$) } & World Development Indicators, World Bank \\
\hline & FDI Database, World Investment Report, UNCTAD \\
\hline Real GDP per capita (constant US\$) & World Development Indicators, World Bank \\
\hline \multirow{2}{*}{ Nominal GDP (US\$) } & World Development Indicators, World Bank \\
\hline & UN Common Database \\
\hline Nominal GDP (Local Currency) & International Financial Statistics, IMF (line 99B..ZF) \\
\hline Real GDP per capita growth rate & World Development Indicators, World Bank \\
\hline \multicolumn{2}{|c|}{$\begin{array}{l}\text { General government final consumption expenditure / World Development Indicators, World Bank } \\
\text { GDP }\end{array}$} \\
\hline \multirow{4}{*}{ General government final consumption expenditure } & World Development Indicators, World Bank \\
\hline & SDDS, Asian Development Bank \\
\hline & UN Common Database \\
\hline & UN National Accounts Main Aggregates Database \\
\hline Gross Capital Formation / GDP & World Development Indicators, World Bank \\
\hline \multirow{5}{*}{ Gross Capital Formation } & World Development Indicators, World Bank \\
\hline & SDDS, Asian Development Bank \\
\hline & UN Common Database \\
\hline & International Financial Statistics, IMF \\
\hline & UN National Accounts Main Aggregates Database \\
\hline Population & World Development Indicators, World Bank \\
\hline \multirow{2}{*}{ Trade Openness } & World Development Indicators, World Bank \\
\hline & UN National Accounts Main Aggregates Database \\
\hline Liquid Liabilities / GDP & A New Database on Financial Development and Structure \\
\hline $\begin{array}{l}\text { Private Credit by Deposit Money Banks } \\
\text { and Other Financial Institutions / GDP }\end{array}$ & A New Database on Financial Development and Structure \\
\hline Liquid Liabilities & $\begin{array}{l}\text { International Financial Statistics, IMF (line 55L..ZF or, if not available, line } \\
\text { 35L..ZF) }\end{array}$ \\
\hline $\begin{array}{l}\text { Private Credit by Deposit Money Banks } \\
\text { and Other Financial Institutions }\end{array}$ & $\begin{array}{l}\text { International Financial Statistics, IMF (lines } 22 \mathrm{~d} \text { and } 42 \mathrm{~d} \text {; } \\
\text { or line } 22 \mathrm{~d} \text { only if line } 42 \mathrm{~d} \text { is unavailable) }\end{array}$ \\
\hline Secondary Enrolment Ratio & World Development Indicators, World Bank \\
\hline \multirow{2}{*}{ Total Gross Secondary Enrolment } & UN Common Database \\
\hline & Yearbook of Statistics Singapore (for Singapore data) \\
\hline \multirow{4}{*}{$\mathrm{CPI}$} & UNESCO Institute for Statistics \\
\hline & World Development Indicators, World Bank \\
\hline & International Financial Statistics, IMF (line 64..ZF) \\
\hline & UN Common Database \\
\hline \multirow{4}{*}{ GDP Deflator $(2000=100)$} & CEIC Global Database \\
\hline & World Development Indicators, World Bank \\
\hline & International Financial Statistics, IMF \\
\hline & UN Common Database \\
\hline Government Effectiveness & Governance Matters V: Governance Indicators for 1996-2005 \\
\hline Nominal Exchange Rate & International Financial Statistics, IMF \\
\hline
\end{tabular}


Table A.3. Definition of Variables for Empirical Analysis

\begin{tabular}{|c|c|}
\hline Variable & Definition \\
\hline growth & Real GDP per capita growth rate, deflated using GDP deflator of base year 2000 \\
\hline fdinflowindex & Index for FDI inflow as a \% of GDP (real terms) \\
\hline dldc & $=1$ for least developed countries, 0 otherwise \\
\hline ddc & $=1$ for developing countries, 0 otherwise \\
\hline liquidindex & Index for financial system liquid liabilities as a \% of GDP (real terms) \\
\hline pcreditindex & $\begin{array}{l}\text { Index for value of credits allocated to private sector by financial intermediaries as a } \% \text { of GDP (real } \\
\text { terms) }\end{array}$ \\
\hline fdiflowindex $\times$ liquidindex & Interaction between FDI inflow index and liquid liabilities index \\
\hline $\begin{array}{l}\text { fdiflowindex } \times \\
\text { pcreditindex }\end{array}$ & Interaction between FDI inflow index and private credit index \\
\hline $\begin{array}{l}\text { dldc } \times \text { fdiflowindex } \times \\
\text { liquidindex }\end{array}$ & Interaction between least developed country dummy, FDI inflow index and liquid liabilities index \\
\hline $\begin{array}{l}\text { ddc } \times \text { fdiflowindex } \times \\
\text { liquidindex }\end{array}$ & Interaction between developing country dummy, FDI inflow index and liquid liabilities index \\
\hline $\begin{array}{l}\text { dldc } \times \text { fdiflowindex } \times \\
\text { pcreditindex }\end{array}$ & Interaction between least developed country dummy, FDI inflow index and private credit index \\
\hline $\begin{array}{l}\text { ddc } \times \text { fdiflowindex } \\
\text { pcredit }\end{array}$ & Interaction between developing country dummy, FDI inflow index and private credit index \\
\hline ligdppc & $\begin{array}{l}\text { Log of initial real GDP per capita in US\$ (at period } t-1 \text { ), deflated using GDP deflator of base year } \\
2000\end{array}$ \\
\hline $\operatorname{lgcf}$ & Log of gross capital formation as a \% of GDP (real terms) \\
\hline lgovtcons & Log of general government final consumption expenditure as a $\%$ of GDP (real terms) \\
\hline lopenness & Log of exports plus imports as a \% of GDP (real terms) \\
\hline dldc $\times$ lopenness & Interaction between least developed country dummy and trade openness \\
\hline ddc $\times$ lopenness & Interaction between developing country dummy and trade openness \\
\hline secenrindexi & Index for secondary enrolment ratio (a proxy for level of human capital) \\
\hline $\begin{array}{l}\text { fdiflowindex } \times \\
\text { secenrindexi }\end{array}$ & Interaction between FDI inflow index and secondary enrolment ratio index \\
\hline popgrowth & Annual population growth rate \\
\hline goveff & Index for Government Effectiveness \\
\hline
\end{tabular}

